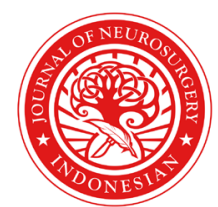

\title{
Endoscopic Third Ventriculostomy (ETV) versus Ventriculoperitoneal Shunt (VPS) for pediatric hydrocephalus: a meta-analysis
}

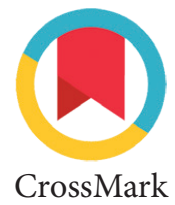

\author{
Mohamad Saekhu, ${ }^{1 *}$ Eko Suryo Pujiastono, ${ }^{2}$ Fabianto Santoso ${ }^{3,4}$
}

\section{ABSTRACT}

Background: Using Endoscopic Third Ventriculostomy (ETV) or Ventriculoperitoneal Shunt (VPS) as standard technique of cerebrospinal fluid (CSF) diversion has been a debatable issue. To date, a meta-analysis on the best treatment for pediatric hydrocephalus is yet to be done. ETV has been reported to have successful outcomes in many studies. The objective of this metaanalysis is to know the effectiveness of ETV compared to VPS in pediatric hydrocephalus.

Methods: This study used electronic articles published in PubMed, EBSCO, and Google Scholar from January 1990 until January 2017. Articles included were full-text observational study or randomized control trial in Bahasa or English. Surgical failure was compared for this meta-analysis. Statistical analysis was done by using Review Manager 5.

Results: Five articles met our inclusion and exclusion criteria. The pooled risk ratio (ETV vs. VPS) of surgical failure was $0.95[0.76,1.19]$ for fixed effect model. This analysis had no or little heterogeneity $\left(I^{2}=18 \% ; X^{2}=0.25\right)$.

Conclusion: In one year follow up, there is no superiority between both procedures in surgical failure. Limited studies have been conducted to compare the effectiveness of ETV compared with VPS for pediatric hydrocephalus management. Further studies comparing both treatments are required to know the best management for pediatric hydrocephalus.

Keywords: ETV, VPS, pediatric hydrocephalus, meta-analysis

Cite This Article: Saekhu,M., Pujiastono, E.S., Santoso, F. 2018. Endoscopic Third Ventriculostomy (ETV) versus Ventriculoperitoneal Shunt (VPS) for pediatric hydrocephalus: a meta-analysis. Indonesian Journal of Neurosurgery 1(1): 10-18. D01:10.15562/ijn.v1i1.14

'Consultant, Department of Neurosurgery, Cipto Mangunkusumo National Hospital - Faculty of Medicine Universitas Indonesia, Jakarta, Indonesia

${ }^{2}$ Consultant, Department of Neurology, Hadji Boejasin Hospital, Pelaihari, South Borneo,

${ }^{3}$ Alumni of Faculty of Medicine Universitas Indonesia

${ }^{4}$ Intern Doctor, Hadji Boejasin Hospital, Pelaihari, South Borneo, Indonesia
*Correspondence to: Mohamad Saekhu, Department of Neurosurgery Cipto Mangunkusumo National Hospital - Faculty of Medicine Universitas Indonesia saekhu2010@gmail.com

\section{BACKGROUND}

Hydrocephalus is one of the most common pediatric neurological diseases. ${ }^{1}$ The prevalence of this disease is higher in developing than developed countries. $^{2}$ In developed countries, the incidence of congenital hydrocephalus is about 0.5 to 1 case per 1000 births, whereas the incidence of neonatal acquired hydrocephalus is 3 to 5 cases per 1000 births. ${ }^{3}$ The USA has the prevalence of infant hydrocephalus roughly one per 1000 births. ${ }^{4}$ In Indonesia, no definitive data on the epidemiology of hydrocephalus till date. Department of Neurosurgery in Medan, North Sumatra, Indonesia reported that cases of pediatric hydrocephalus are about $40-50 \%$ out of the total amount of patients who visited neurology and neurosurgery clinic or underwent an operation. ${ }^{5}$ Another study in Bali, Indonesia reported that prevalence of pediatric hydrocephalus is 10 cases per 1000 births. ${ }^{6}$ In Dr. Soetomo Hospital, Surabaya, Indonesia, among the patients who have hydrocephalus, $41.25 \%$ have communicating hydrocephalus, and the rest have non-communicating hydrocephalus.?

Cerebrospinal Fluid (CSF) diversion is the main treatment for hydrocephalus. There are several techniques of diversion, but the preferred method in
Indonesia is through shunt catheter, especially ventriculoperitoneal shunt (VPS). However, the results of VPS are still vague with high shunt-associated failure rate $(25-36 \%)$. In the early of $20^{\text {th }}$ century, ETV, the new technique for pediatric hydrocephalus emerged. This newly founded technique shows a promising result, but some studies reported that ETV also has a high failure rate. ${ }^{8}$ The failure rate is an important issue in this case because it may affect children's health and healthcare expenditure. ${ }^{9}$

The selection of VPS or ETV for hydrocephalus management is a debatable topic. Limbrick Jr DD et al., in their systematic review about the performance of VPS and ETV for pediatric hydrocephalus, concluded that VPS and ETV have equivalent outcomes in the clinical etiologies studied. ${ }^{10}$ Nevertheless, that systematic review does not explain about using statistics for their analysis. Currently, there is no meta-analysis on the best treatment for pediatric hydrocephalus. In order to find the solution on pediatric hydrocephalus management, we conducted a meta-analysis. The study aimed to figure out the best treatment option for pediatric hydrocephalus, especially non-communicating hydrocephalus. 


\section{MATERIAL AND METHODS}

A literature search was carried out using several search engines: PubMed, EBSCO, and Google Scholar. The keywords used were ("endoscopic third ventriculostomy" OR "ETV") AND ("ventriculoperitoneal shunt" OR "VPS") AND "hydrocephalus" AND ("pediatric" OR "children" OR "infant" OR "neonate"). The searching was limited by date of publication, from January 1990 to January 2017. Only articles in Bahasa and English were included. Citation alert was also applied in the searching process. Our PICO and searching strategy were mentioned in Table 1 and Figure 1.

\section{Criteria for included studies Types of Studies}

This review used all observational study or randomized control trials (RCT) investigating ETV versus VPS as a treatment for pediatric hydrocephalus. Only full-text studies were included. Unpublished articles and abstracts were excluded from the study.

Table 1 PICO of the study

\begin{tabular}{ll}
\hline Patient & Pediatric obstructive / non communicating hydrocephalus \\
Intervention & Endoscopic Third Ventriculostomy (ETV) \\
Comparison & Ventricular-peritoneal shunt (VPS) \\
Outcome & Surgery failure \\
\hline
\end{tabular}

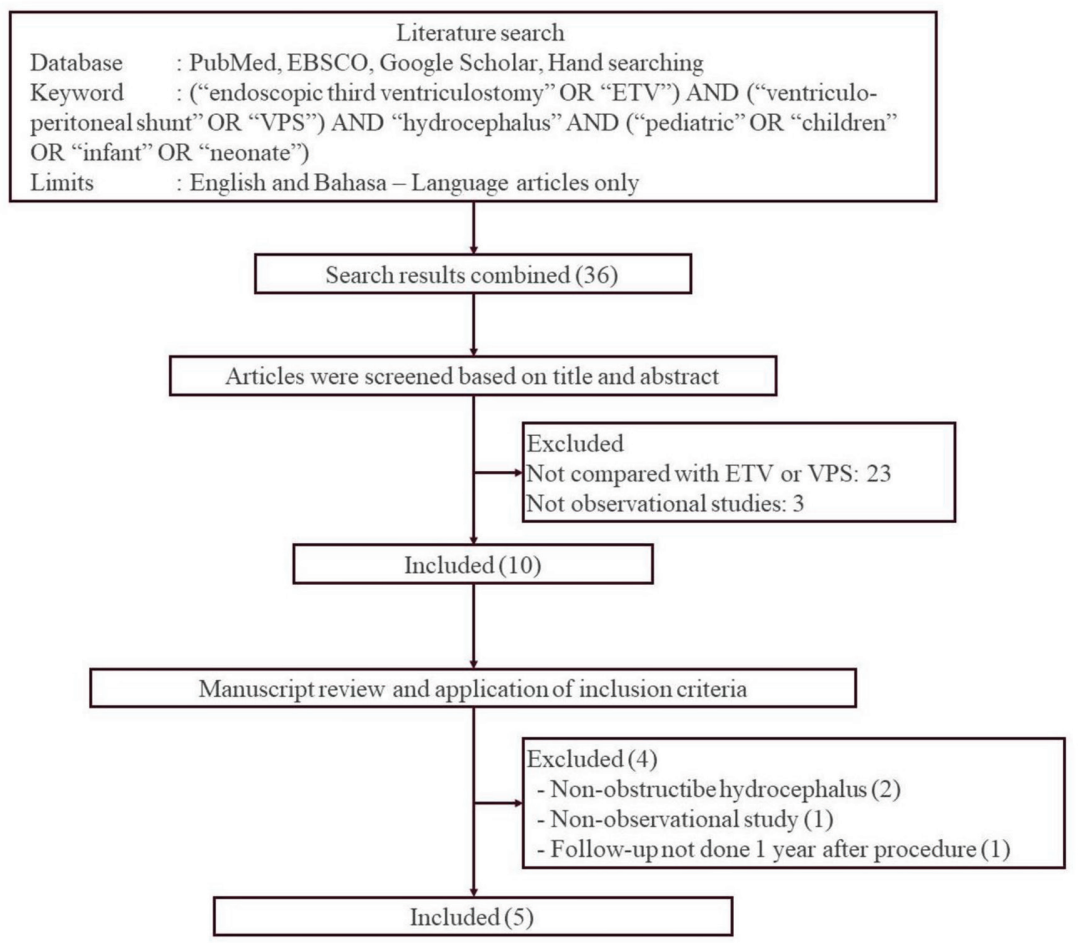

Figure 1 Study flow diagram

\section{Types of participants}

The participants were children ( $0-18$ years) with obstructive/non-communicans hydrocephalus caused by any etiology underwent either ETV or VPS.

\section{Types of interventions}

The interventions were ETV in comparison to VPS as the standard procedure. Those procedures could be performed electively or as emergency procedures. Both single procedure and concomitant procedures were included in this study.

\section{Types of outcome measures}

The primary outcome of the intervention was the failure of the first surgical treatment. Failure can be caused by infection, mechanical failure of the shunt or non-functioning ETV. The diagnosis of a non-functioning ETV was made according to clinical criteria in patients with signs of increased intracranial pressure or growing head circumference and increase in ventricular size on imaging (usually CT). Failure of the Cerebro Spinal Fluid (CSF) shunt (on VPS treatments) was detected by the presence of shunt obstruction, shunt over drainage, loculated ventricles or shunt infection. The secondary outcome was the duration of the procedure.

\section{Study selection and data extraction}

All studies were screened for duplication manually. Consequently, duplication-free articles were further examined by their titles and abstracts using predetermined inclusion and exclusion criteria mentioned above. Studies were selected by two authors independently. Discrepancies were resolved by discussion. Studies that fulfilled inclusion and exclusion criteria were then underwent full-text review. The incidence of surgical failures from each eligible full texts were extracted and analyzed.

\section{Assessment of bias and statistical methods}

This study used Cochrane Risk of Bias assessment tools to evaluate interventional studies' quality. The quality of the studies was assessed by two independent authors. Quantitative synthesis of included studies with risk ratio as its effect size was measured using Review Manager 5.0 software. Heterogeneity of studies was determined using chi-square and $\mathrm{I}^{2}$. A fixed-effects model was performed when $p>$ 0.05 , but, a random-effect model was analyzed when $p<0.05$.

\section{RESULTS}

Out of three databases and hand searching procedure, there were 36 articles collected. After further 


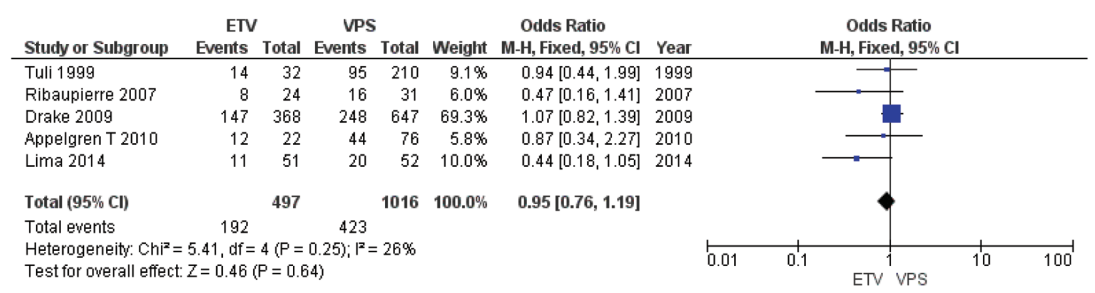

Figure 2 Forest plot comparing ETV and VPS

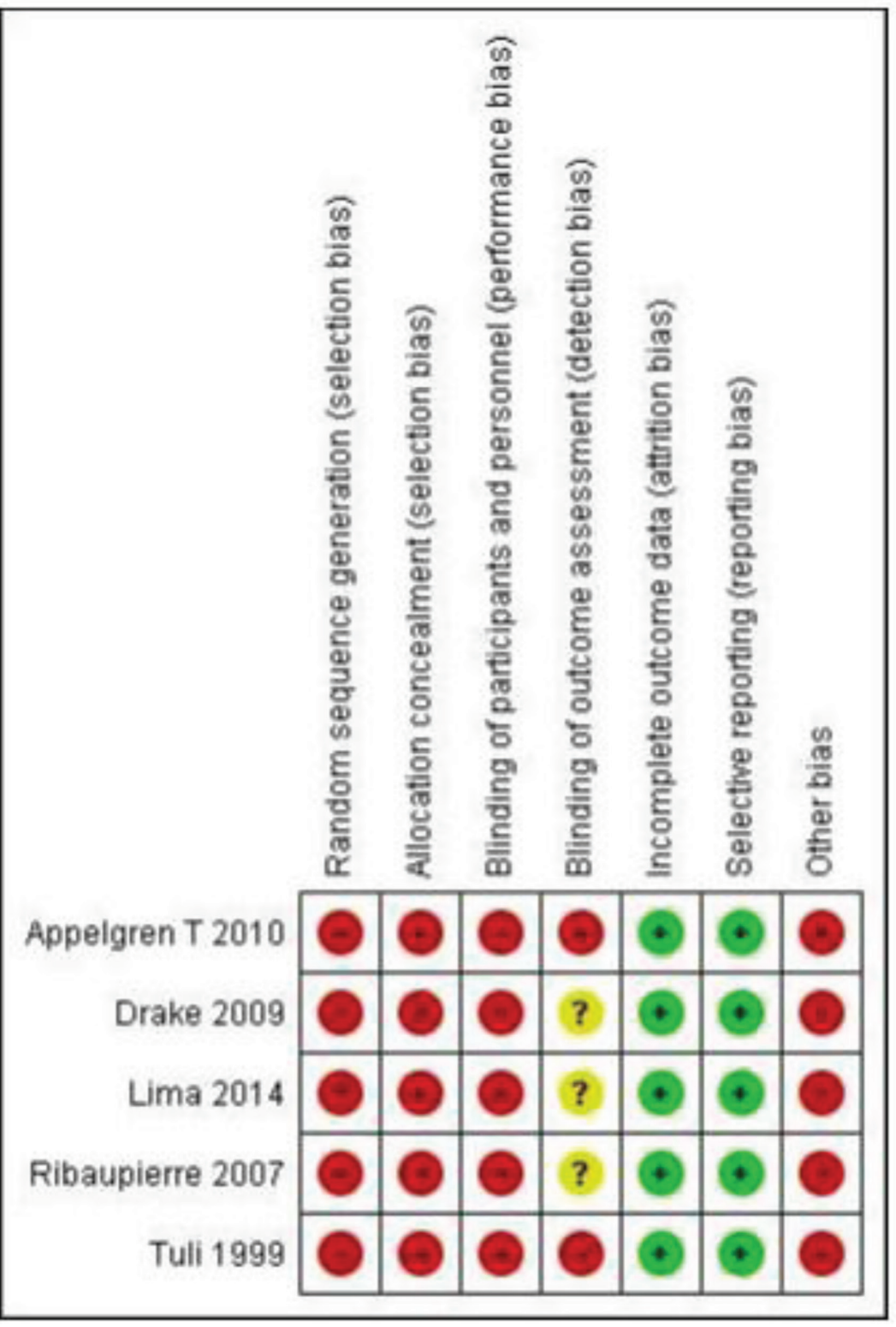

Figure 3 Risk of bias summary

breakdown, five articles were included for final assessment. Some articles were excluded due to not comparing ETV and VPS, non-observational study, no post-study follow-up and studies with non-obstructive hydrocephalus patients. Three out of five selected studies used retrospective cohort design, and the others were prospective cohort with the level of evidence ranging from $1 b$ to $2 c$. From those studies, the intervention was done on 1,513 children age 0-18 years old across North America and European countries (497 patients in ETV group and 1,016 patients in VPS group).

Further analysis was performed to compare the surgical failure between each procedure (ETV vs VPS). Figure 2 shows $41.63 \%$ and $38.63 \%$ surgical failure in VPS and ETV group, respectively. From fixed effect model analysis with little heterogeneity $\left(I^{2}=26 \% ; X^{2}=0.25\right)$, pooled risk ratio between ETV and VPS on surgical failure was 0.95 ( $p=0.64 ; 95 \%$ CI: 0.76-1.19).

Regarding biases, all of the studies are subject to selection and performance bias with no randomization, allocation concealment and blinding of participants and personnel. On the contrary, attrition bias and reporting bias was unseen in these study. Detection bias was clearly visible in studies by Appelgren et al. and Tuli et al., but not in studies by Drake et al., Lima et al., and Ribaupierre et al. Overall, all studies had a poor control on biases.

\section{DISCUSSION}

Even though only five articles could be used for further analysis, little evidence of heterogeneity was found among studies. The systematic review by Limbrick Jr DD, et al. in 2014 with six articles, four of which are used in this study, showed that both ETV and CSF shunt could be used in managing pediatric hydrocephalus. ${ }^{10}$

Our result indicated that there was no significant difference in surgical failure between ETV and VPS. Several factors are thought to affect this result, including the variation on patients' ages, duration of follow up, the design of the studies, surgery skill, cost of surgery and availability of surgical instruments, and biases of the studies.

First, the variation in the age of the patients may influence the outcome. Some studies underlined age as an important factor. They claimed that ETV had a better outcome in older children. ${ }^{11}$ Jernigan et al. showed that ETV was not superior to VPS in infant (younger than 1 year). ${ }^{8}$ This evidence was supported by Drake et al., who explained that several plausible mechanisms for the young age; such as thin skin, the propensity of CSF to leak out, immature immune system, and underdeveloped CSF absorption pathway that could affect the result of procedures. ${ }^{11}$ The ages of majority of patients in studies which we used were ranging from newborn to 18 years old.

The second factor is the duration of follow up. In the study by Drake et al., which adjusted for age and hydrocephalus etiology, resulted that ETV failure 
was higher than shunt surgery in early follow-up. After three months, ETV failure rate was lower than shunt surgery. ${ }^{11}$ This meta-analysis used one year of follow-up, and our result shows that ETV and VPS have a similar failure rate.

Furthermore, design study may also affect the result of the study. Majority of the studies used were observational studies, especially retrospective observational study without randomization. In terms of therapeutic study, the highest level of evidence level is randomized control trial (RCT). However, this bias factor may be tolerated due to ethical issue and difficulty of blinding in surgical procedures.

Additional factors which may affect the result are surgery skill, and cost of the surgery and surgical instrument. Cost of surgery could influence our decision in choosing the procedure. Although not being discussed in this meta-analysis, Lima et al. showed that the initial cost of ETV is higher than VPS. However, after one year follow-up, there is no statistical difference between the cost of both procedure. ${ }^{12}$ Regarding surgical instruments, many hospitals in developing country, such as Indonesia, do not have endoscope to perform ETV for hydrocephalus management.

Besides the biases mentioned above, several limitations are found in this study. We do not split analysis on patient age; however, almost all studies did not report failure rate based on the age of the patient. Another bias that may affect the result is the duration of follow up, but only a few studies did an analysis on this with a varied division of follow-up length among studies. In addition, further analysis on failure etiologies (infection, mechanical failure of the shunt, and non-functioning ETV) was not done in this study because only one study divided the result into infections and other failure etiologies. These limitations can be considered in implementing future studies on ETV and VPS for pediatric hydrocephalus, especially obstructive hydrocephalus.

\section{CONCLUSION}

In one year follow up, there is no superiority between both procedures in surgical failure. Limited studies have been conducted to compare the effectiveness of ETV and VPS for the management of pediatric hydrocephalus. More studies are required to know the best management for pediatric hydrocephalus.

\section{DISCLOSURE}

The authors report no conflicts of interest in this study.

\section{REFERENCE}

1. Kahle KT, Kulkarni AV, Limbrick Jr DD, Warf BC. Hydrocephalus in children. Lancet. 2016;387:788-89.

2. Warf BC. Hydrocephalus in Uganda: the predominance of infectious origin and primary management with endoscopic third ventriculostomy. J Neurosurg (Pediatrics 1). 2005;102:1-15.

3. Muir RT, Wang S, Warf BC. Global surgery for pediatric hydrocephalus in the developing world: a review of history, challenges, and future directions. Neurosurg Focus. 2016;41(5):E11.

4. Tully HM, Dobyns WB. Infantile hydrocephalus: a review of epidemiology, classification, and causes. Eur J Med Genet. 2014;57(8):359-68.

5. Ibrahim S, Rosa AB, Harahap AR. Hydrocephalus in children. In: Sastrodiningrat AD. Neurosurgery Lecture Notes. $1^{\text {st }}$ Ed. Medan:USU Press;2012. Page 671-80.

6. Maliawan S, Andi AI, Bakta M. Teknik endoscopic third ventriculostomy dibandingkan dengan ventriculoperitoneal shunting pada hidrosefalus obstruktif: perbaikan klinis dan perubahan interleukin-1 $\beta$, interleukin-6, dan neural growth factor cairan serebrospinalis [dissertation]. Denpasar: Universitas Udayana;2008.

7. Rahmayani DD, Gunawan PI, Utomo B. Profil klinis dan faktor risiko hidrosefalus komunikans dan non komunikans pada anak di RSUD dr. Soetomo. Sari Pediatri. 2017;19(1):25-31.

8. Jernigan SC, Berry JG, Graham DA, Goumnerova L. The comparative effectiveness of ventricular shunt placement versus endoscopic third ventriculostomy for initial treatment of hydrocephalus in infants. J Neurosurg Pediatrics. 2014;13:295-300.

9. Tuli S, Drake J, Lawless J, Wigg M, Lamberti-Pasculli M. Risk factor for repeated cerebrospinal shunt failures in pediatric patients with hydrocephalus. J Neurosurg. 2000;92:31-38

10. Limbrick Jr DD, Baird LC, Klimo Jr P, Riva-Cambrin J, Flannery AM. Pediatric hydrocephalus: systematic literature review and evidence-based guidelines. Part 4: Cerebrospinal fluid shunt or endoscopic third ventriculostomy for the treatment of hydrocephalus in children. J Neurosurg Pediatrics (Suppl). 2014;14:30-34.

11. Drake JM, Kulkarni AV, Kestle J. Endoscopic third ventriculostomy versus ventriculoperitoneal shunt in pediatric patients: a decision analysis. Childs Nerv Syst. 2009;25:467-72. (Reference included in this study)

12. Lima Bod, Pratesi R. Endoscopic third ventriculostomy has no higher costs than ventriculoperitoneal shunt. Arq Neuropsiquiatr. 2014;72(7):524-27. (Reference included in this study)

\section{Reference Included in This Study}

Ribaupierre S, Rilliet B, Vernet O, Regli L, Villemure JG. Third ventriculostomy vs ventriculoperitoneal shunt in pediatric obstructive hydrocephalus: results from a Swiss series and literature review. Childs Nerv Syst. 2007;23:527-33.

Appelgren T, Zetterstrand S, Elversson J, Nilsson D. Longterm outcome after treatment of hydrocephalus in children. Pediatr Neurosurg. 2010;46:221-26.

Tuli S, Alshail E, Drake J. Third ventriculostomy versus cerebrospinal fluid shunt as a first procedure in pediatric hydrocephalus. Pediatr Neurosurg. 1999;30:11-15.

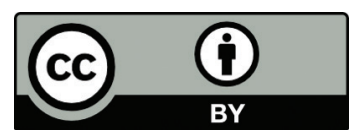

This work is licensed under a Creative Commons Attribution 
SUMMARY OF FINDINGS FOR THE MAIN COMPARISON

\begin{tabular}{|c|c|c|c|c|c|c|c|c|}
\hline $\begin{array}{l}\text { Study } \\
\text { author }\end{array}$ & Type of study & $\begin{array}{l}\text { Level of } \\
\text { Evidence }\end{array}$ & Subject condition & Intervention & $\mathbf{n}$ & Control & $\mathbf{n}$ & Outcome \\
\hline $\begin{array}{l}\text { Lima et al. } \\
(2014)\end{array}$ & $\begin{array}{l}\text { Observational } \\
\text { study, prospective } \\
\text { cohort }\end{array}$ & $1 b$ & $\begin{array}{l}\text { Children who had } \\
\text { hydrocephalus surgical } \\
\text { treatment at Hospital de Base } \\
\text { do Distrito Federal (HBDF); } \\
\text { data collected from 2007-2008 }\end{array}$ & ETV & 51 & VPS & 52 & $\begin{array}{l}\text { ETV: } 11 \text { failures } \\
(22 \%) \\
\text { VPS: } 20 \text { failures } \\
(38 \%)\end{array}$ \\
\hline $\begin{array}{l}\text { Ribaupierre } \\
\text { et al. (2007) }\end{array}$ & $\begin{array}{l}\text { Observational } \\
\text { study, retrospective } \\
\text { cohort }\end{array}$ & $2 c$ & $\begin{array}{l}\text { Children ( } 0 \text { - } 18 \text { years old) who } \\
\text { were diagnosed obstructive } \\
\text { hydrocephalus for the } \\
\text { first time; from January } \\
\text { 1990-December } 2004\end{array}$ & ETV & 24 & VPS & 31 & $\begin{array}{l}\text { ETV: } 8 \text { failures } \\
(33 \%) \\
\text { VPS: } 16 \text { failures } \\
(52 \%)\end{array}$ \\
\hline $\begin{array}{l}\text { Tuli et al. } \\
\text { (1999) }\end{array}$ & $\begin{array}{l}\text { Observational } \\
\text { study, prospective } \\
\text { cohort }\end{array}$ & $1 b$ & $\begin{array}{l}\text { Patients aged newborn to } \\
18 \text { years with diagnosis of } \\
\text { hydrocephalus caused by } \\
\text { aqueductal stenosis or tumor } \\
\text { as a cause. }\end{array}$ & TV & 32 & VPS & 210 & $\begin{array}{l}\text { TV: } 14 \text { failures } \\
\text { (44\%) } \\
\text { VPS: } 95 \text { failures } \\
(45 \%)\end{array}$ \\
\hline $\begin{array}{l}\text { Applegren } \\
\text { et al. }(2010)\end{array}$ & $\begin{array}{l}\text { Observational } \\
\text { study, retrospective } \\
\text { cohort }\end{array}$ & $2 b$ & $\begin{array}{l}\text { Patients aged } 0-18 \text { years, } \\
\text { had a primary ETV or VPS } \\
\text { performed between } 2001 \text { and } \\
2005\end{array}$ & ETV & 22 & VPS & 76 & $\begin{array}{l}\text { ETV: } 12 \text { failures } \\
\text { (55\%) } \\
\text { VPS: } 44 \text { failures } \\
(58 \%)\end{array}$ \\
\hline $\begin{array}{l}\text { Drake et al. } \\
(2009)\end{array}$ & $\begin{array}{l}\text { Observational } \\
\text { study, retrospective } \\
\text { cohort }\end{array}$ & $2 b$ & $\begin{array}{l}\text { ETV data are from Canadian } \\
\text { pediatric neurosurgery study } \\
\text { group. VPS data are from the } \\
\text { shunt design trial and } \\
\text { the endoscopic shunt insertion } \\
\text { trial }\end{array}$ & ETV & 368 & VPS & 647 & $\begin{array}{l}\text { ETV: } 147 \text { failures } \\
\text { (40\%) } \\
\text { VPS: } 248 \text { failures } \\
(38.3 \%)\end{array}$ \\
\hline
\end{tabular}

TV = Third ventriculostomy

ETV = Endoscopic third ventriculostomy

VPS $=$ Ventriculoperitoneal shunt

\section{CHARACTERISTIC OF STUDIES}

1. Endoscopic third ventriculostomy has no higher costs than ventriculoperitoneal shunt (Lima et al., 2013)

\begin{tabular}{ll}
\hline Methods & - Study design: prospective cohort \\
Participants & Power calculation: No \\
& -
\end{tabular}




\begin{tabular}{|c|c|c|}
\hline Bias & Authors'judgment & Support for judgement \\
\hline Random sequence generation (selection bias) & High risk & Choice of treatment was decided by the neurosurgeon on call \\
\hline Allocation concealment (selection bias) & High risk & Technique of surgery, no concealment can be done \\
\hline $\begin{array}{l}\text { Blinding of participants and personnel } \\
\text { (performance bias) All outcomes }\end{array}$ & High risk & Technique of surgery, no blinding can be done \\
\hline $\begin{array}{l}\text { Blinding of outcome assessment (detection bias) } \\
\text { All outcomes }\end{array}$ & Unclear risk & Not mention on blinding of outcome assessment \\
\hline $\begin{array}{l}\text { Incomplete outcome data (attrition bias) } \\
\text { All outcomes }\end{array}$ & Low risk & No missing data \\
\hline Selective reporting (reporting bias) & Low risk & All outcome were reported \\
\hline Other bias & High risk & \\
\hline
\end{tabular}

\section{- ETV vs VPS}

\begin{tabular}{lcl}
\hline & Failure & Normal \\
\hline ETV group & $11(22 \%)$ & $40(78 \%)$ \\
VPS group & $20(38 \%)$ & $32(62 \%)$ \\
\hline
\end{tabular}

2. Third ventriculostomy vs ventriculoperitoneal shunt in pediatric obstructive hydrocephalus: Results from a Swiss series and literature review (Ribaupierre, 2007)

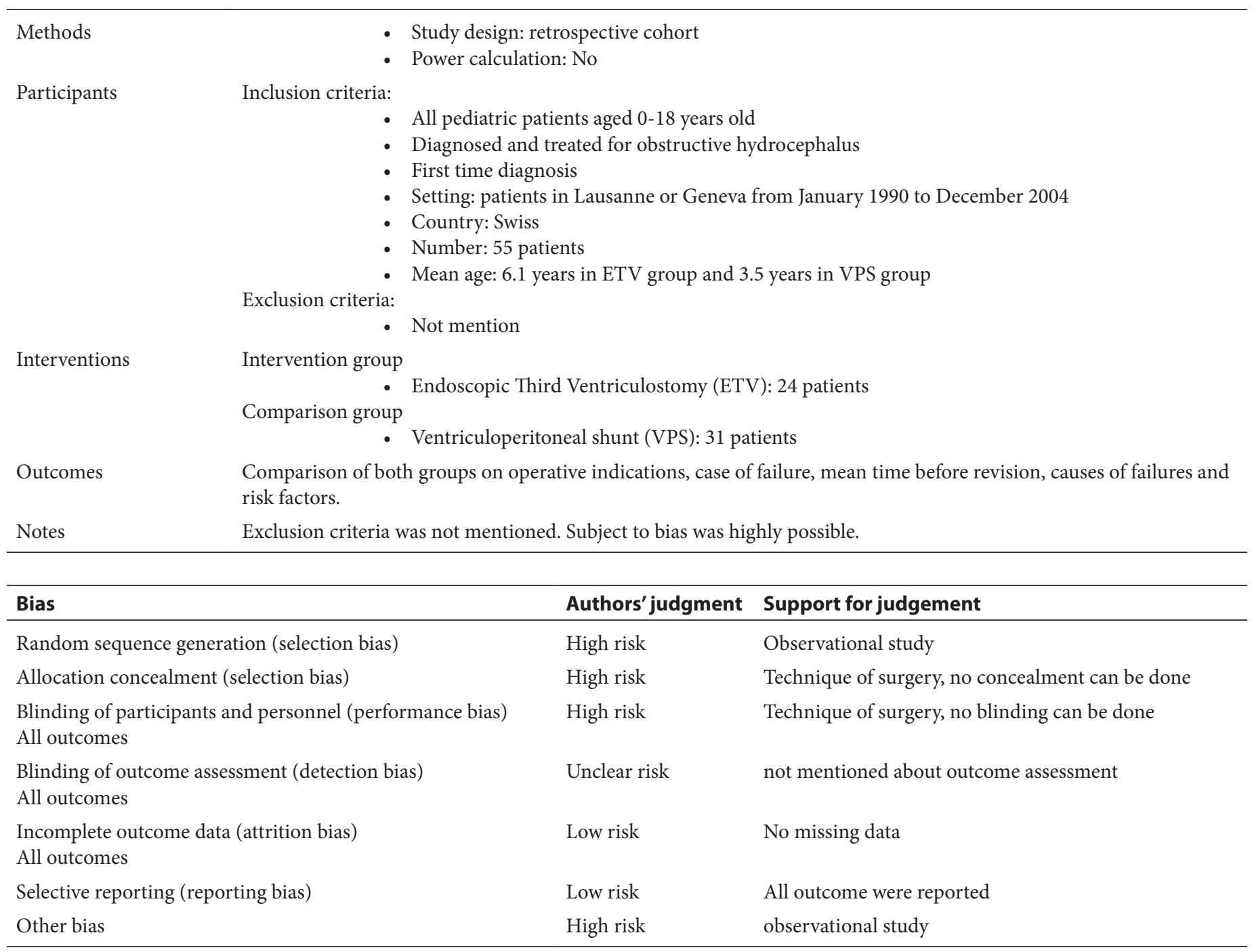




\begin{tabular}{lll}
\hline & \multicolumn{1}{c}{ Failure } & Normal \\
\hline ETV group & $8(33 \%)$ & $16(67 \%)$ \\
VPS group & $16(52 \%)$ & $15(48 \%)$ \\
\hline
\end{tabular}

3. Long-Term Outcome after Treatment of Hydrocephalus in Children (Applegren et al., 2010)

\begin{tabular}{|c|c|c|c|}
\hline \multicolumn{2}{|l|}{ Methods } & \multicolumn{2}{|c|}{$\begin{array}{l}\text { - Study design: observational study, retrospective cohort } \\
\text { - Power calculation: No }\end{array}$} \\
\hline Participants & \multicolumn{3}{|c|}{ 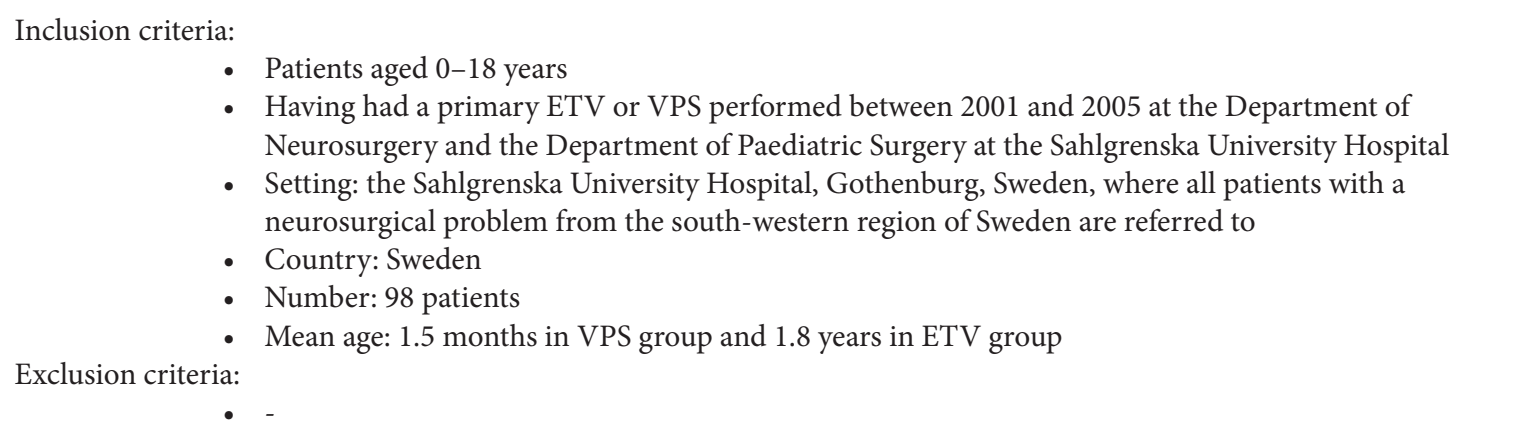 } \\
\hline Interventions & \multicolumn{3}{|c|}{$\begin{array}{c}\text { Comparison group } \\
\bullet \text { CSF shunt (VPS) }: 76 \text { patients }\end{array}$} \\
\hline Outcomes & \multicolumn{3}{|c|}{$\begin{array}{l}\text { Failur of the first surgical treatment, requiring new surgery. } \\
\text { Duration of procedure }\end{array}$} \\
\hline \multicolumn{4}{|l|}{ Notes } \\
\hline \multicolumn{2}{|l|}{ Bias } & Authors' judgment & Support for judgement \\
\hline \multicolumn{2}{|c|}{ Random sequence generation (selection bias) } & High risk & $\begin{array}{l}\text { All patients aged } 0-18 \text { years having primary ETV or VPS performed } \\
\text { between } 2001 \text { and } 2005 \text { are included }\end{array}$ \\
\hline \multicolumn{2}{|c|}{ Allocation concealment (selection bias) } & High risk & Since it is technique of surgery, concealment could not be done. \\
\hline \multicolumn{2}{|c|}{$\begin{array}{l}\text { Blinding of participants and personnel } \\
\text { (performance bias) All outcomes }\end{array}$} & High risk & Since it is technique of surgery, blinding could not be done. \\
\hline \multicolumn{2}{|c|}{$\begin{array}{l}\text { Blinding of outcome assessment (detection bias) } \\
\text { All outcomes }\end{array}$} & High risk & No blinding outcome assessment \\
\hline \multicolumn{2}{|c|}{$\begin{array}{l}\text { Incomplete outcome data (attrition bias) } \\
\text { All outcomes }\end{array}$} & Low risk & All patients had outcome \\
\hline \multicolumn{2}{|c|}{ Selective reporting (reporting bias) } & Low risk & All outcome were reported \\
\hline \multicolumn{2}{|c|}{ Other bias } & High risk & Observational study \\
\hline
\end{tabular}

\section{- $\quad$ ETV vs VPS}

\begin{tabular}{lll}
\hline & Failure & Normal \\
\hline ETV group & $12(55 \%)$ & $10(45 \%)$ \\
VPS group & $44(58 \%)$ & $32(42 \%)$ \\
\hline
\end{tabular}


4. Endoscopic third ventriculostomy versus ventriculoperitoneal shunt in pediatric patients: a decision analysis (Drake et al., 2009)

Methods

Participants

Interventions

Outcomes

Notes
- Study design: Observational study, retrospective cohort

- Power calculation: No

Inclusion criteria:

- Data outcome events from ETV was extracted from the raw data from a Canadian cooperative ETV study involving 368 patients

- Data for the outcomes for CSF shunt insertion were extracted from two prospective randomized CSF shunt trials; one, a comparison of three shunt designs from nine centers, seven North American and two European, and the other, the use of endoscopic ventricular catheter placement from 16 centers, 14 North American and two European

- Number: 1015 participants, 368 in ETV group, 647 in VPS group

- Mean age: 6.5 years in ETV group, 1.6 years in VPS group

Exclusion criteria

- -

Intervention group

Comparison group

- $\quad$ ETV : 368 patients

- VPS : 647 patients

Failure of the procedure

\begin{tabular}{|c|c|c|}
\hline Bias & Authors' judgment & Support for judgement \\
\hline Random sequence generation (selection bias) & High risk & No random sequence applied \\
\hline Allocation concealment (selection bias) & High risk & Since it is technique of surgery, concealment could not be done. \\
\hline $\begin{array}{l}\text { Blinding of participants and personnel } \\
\text { (performance bias) All outcomes }\end{array}$ & High risk & Since it is technique of surgery, blinding could not be done. \\
\hline $\begin{array}{l}\text { Blinding of outcome assessment (detection bias) } \\
\text { All outcomes }\end{array}$ & Unclear risk & NS \\
\hline $\begin{array}{l}\text { Incomplete outcome data (attrition bias) } \\
\text { All outcomes }\end{array}$ & Low risk & All patients had outcome \\
\hline Selective reporting (reporting bias) & Low risk & All outcome were reported \\
\hline Other bias & High risk & Observational study \\
\hline
\end{tabular}

\section{- $\quad$ ETV vs VPS}

\begin{tabular}{lcc}
\hline & Failure & Normal \\
\hline ETV group & $147(40 \%)$ & $221(60 \%)$ \\
VPS group & $248(38.3 \%)$ & $399(61.7 \%)$ \\
\hline
\end{tabular}


5. Third Ventriculostomy versus Cerebrospinal Fluid Shunt as a First Procedure in Pediatric Hydrocephalus (Tuli et al., 1999)

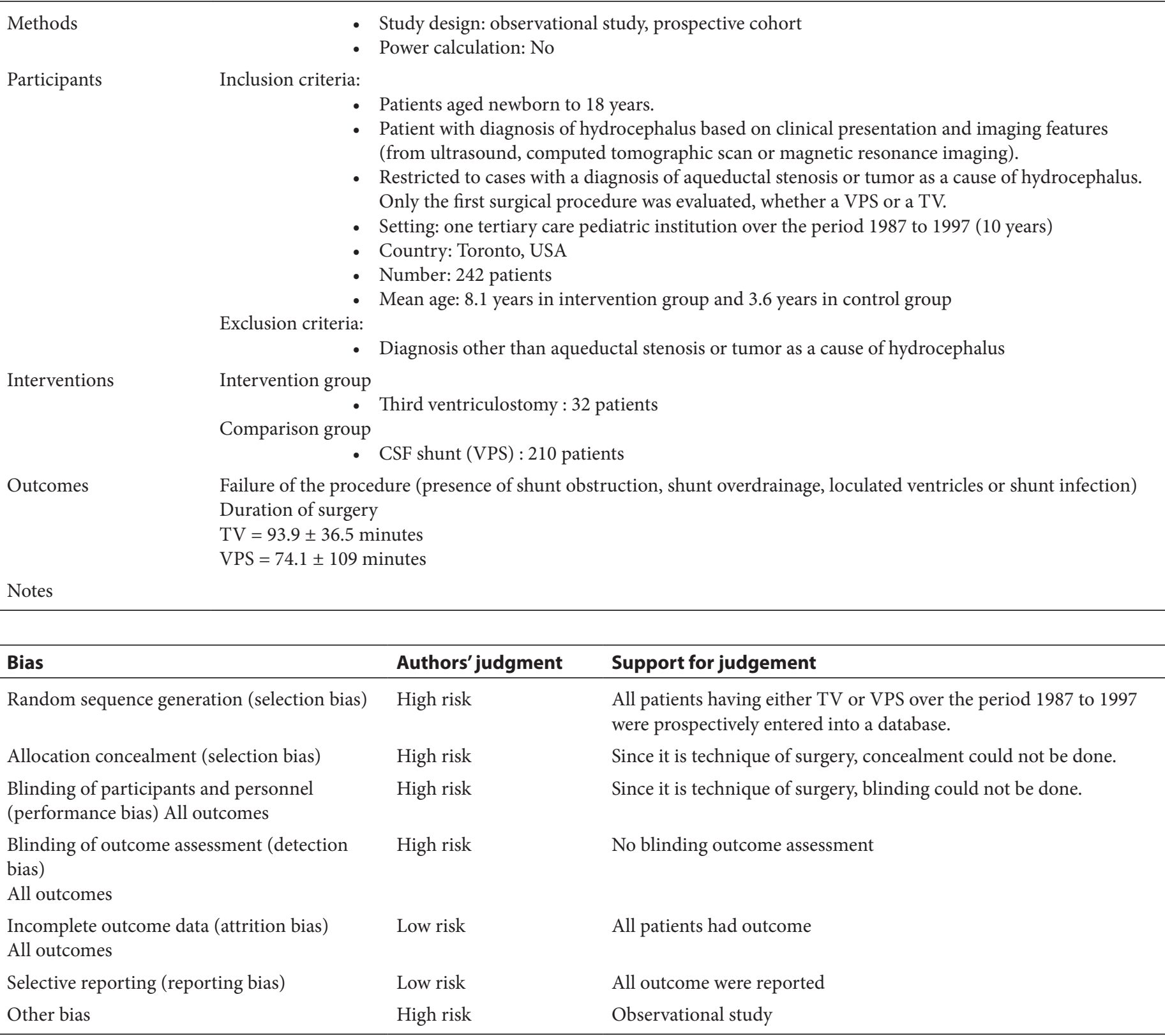

- TV vs VPS

\begin{tabular}{lcc}
\hline & Failure & Normal \\
\hline TV group & $14(44 \%)$ & $18(56 \%)$ \\
VPS group & $95(45 \%)$ & $115(55 \%)$ \\
\hline
\end{tabular}

